\title{
Analisis Loyalitas Karyawan terhadap Produktivitas Kerja
}

\author{
Hani Siti Hanifah \\ Fakultas Ekonomi, Universitas Garut \\ Jalan Raya Samarang No.52a Tarogong Kidul, Kabupaten Garut, Jawa Barat 44151 \\ Hanisiti1965@uniga.ac.id
}

\begin{abstract}
Abstrak- Penelitian ini bertujuan untuk mengetahui bagaimana loyalitas karyawan dan produktivitas kerja karyawan serta pengaruh dari loyalitas karyawan terhadap produktivitas kerja pada CV. Budi Jaya Abadi Garut. Metode yang digunakan dalam penelitian ini adalah metode deskriptif verifikatif, dimana jumlah poluasi sebanyak 324 karyawan dan teknik pengambilan sampel dalam penelitian ini menggunakan probability sampling yaitu dengan rumus slovin menjadi 76 karyawan. Sedangkan alat analisis yang digunakan adalah Analisis Regresi Linier Sederhana.Berdasarkan hasil penelitian ini maka pengujian hipotesis dengan Uji-T diperoleh nilai thitung untuk variabel Loyalitas Karyawan sebesar 2.796 dengan nilai ttabel sebesar 1,67 maka 2.796 >1,67, sesuai dengan hipotesis bahwa thitung > ttabel maka Ho ditolak yang artinya Terdapat Pengaruh Loyalitas Karyawan terhadap Produktivitas Kerja pada CV. Budi Jaya Abadi Garut. Berdasarkan uraian tersebut dapat dipahami bahwa terdapat pengaruh positif dan signifikan antara loyalitas karyawan terhadap produktivitas kerja. Sehingga semakin tinggi loyalitas karyawan maka semakin tinggi pula produktivitas yang dihasilkan.
\end{abstract}

Kata Kunci- loyalitas karyawan; produktivitas kerja.

Abstract- Using a descriptive and verification approach, the present study looks at employee loyalty and how it affects work productivity. 76 out 324 employees at a garment company in Garut, Indonesia, selected using Slovin's formula. Data analysis was performed using simple linear regression analysis. The results t-Test revealed that employee loyalty had a significant positive effect on work productivity with an observed value of 2.796 , higher than the critical $t$ of 1.67 . This finding leads to a conclusion that the more loyal an employee is, the more productive he is.

Keyword: Employee Loyalty, Work Productivity.

\section{PENDAHULUAN}

Setiap organisasi atau perusahaan memiliki visi atau tujuan untuk mencapai keunggulan dalam kinerjanya[1]. kinerja perusahaan yang baik dapat dicapai dengan menggunakan sumberdaya yang optimal dalam operasionalnya[2]. Industri Garmen merupakan salah satu bentuk usaha di bidang busana yang memproduksi pakaian jadi dalam jumlah yang banyak[3]. Industri garmen di Indonesia terus berkembang seiring dengan kebutuhan masyarakat dan jumlah penduduk yang cukup besar sehingga profit yang diperoleh sangat menjanjikan. Hal ini memicu persaingan yang sangat ketat dalam industri garmen, karena bukan hanya dapat memenuhi kebutuhan pasar lokal tetapi juga untuk kebutuhan pasar internasional.

Saat ini terdapat beberapa industri garmen yang berada di wilayah Bandung yang telah memberikan kontribusi bagi perekonomian Indonesia diantaranya PT. Daliatex, PT. Lusatex, PT. Famatex, Dhanar Mas, dan PT. Kahatek yang merupakan pemasok utama untuk sektor tekstil Indonesia dan memberikan kontribusi signifikan terhadap pasar ekspor dengan mengekspor lebih dari 35\% dari produksinya langsung ke tentang banyak negara di seluruh dunia. $45 \%$ adalah
Ekspor tidak langsung dengan perusahaan konsumen, tentang pasokan $20 \%$ untuk pasar domestik[4]. Selain itu di wilayah Garut pun saat ini sudah mulai ditemui beberapa pabrik yang sudah berdiri lebih dari 5 tahun dan merupakan pabrik garmen namun lebih spesifiknya bergerak dibidang jasa yaitu khusus menjahit, memborsdir dan proses finishing, diantaranya PT. Jusindo Sumber Prakarsa dan CV. Budi Jaya Abadi Garut.

Sumber daya manusia memegang peranan penting dalam setiap penyelenggaraan kegiatan perusahaan meskipun peran dan fungsi dari tenaga kerja telah banyak digantikan dengan mesin-mesin industri[5]. Tetapi pada kenyataannya sampai saat ini tenaga kerja masih menjadi faktor yang penting dalam menentukan jalannya proses produksi. Maka dari itu setiap perusahaan menghendaki agar setiap tenaga kerja dapat bekerja secara efektif dan efisien. Rendahnya kualitas tenaga kerja sangat berpengaruh terhadap pengembangan dan peningkatan produksi dalam berbagai bidang. Hal tersebut dikarenakan tenaga kerja memegang peranan penting dalam usaha untuk mencapai tujuan perusahaan. 
CV Budi Jaya Abadi Garut adalah sebuah perusahaan kompeksi di Garut yang merupakan salah satu anak dari produsen Kompeksi Cardinal yang beralamat di Jl. Sudirman Copong-Garut yang bergerak dibidang jasa penjahitan, bordir, dan proses finishing produk dengan merk Cardinal. Perusahaan tersebut telah berdiri hampir 8 tahun di kota Garut dan telah menyerap banyak tenaga kerja khususnya warga Garut. Perusahaan ini juga merupakan perusahaan pertama yang memproduksi salah satu produknya adalah Celana Jeans.

Berikut merupakan data output produksi Celana dengan merk Cardinal, dengan Standar perusahaan dalam pengerjaan 1 pcs celana memerlukan waktu 12 menit per setiap proses pengerjaan yang dalam pengerjaannya memerlukan 1-5 alat proses penjahitan, menggunakan input operator jahit sebanyak 6 line atau rata-rata sebanyak 54 orang per line dengan jam kerja satu hari (waktu) 8 jam, maka output yang harus dihasilkan oleh karyawan jahit sebanyak 46.200 potong celana/bulan. Per-orang harus menghasilkan 68 potong/hari.

Tabel 1. Data Output Celana Selama 12 Bulan Terakhir Periode Januari 2017 - Februari 2018

\begin{tabular}{ccccc}
\hline No. & Bulan & $\begin{array}{c}\text { Targer } \\
\text { Produksi } \\
\text { (Potong) }\end{array}$ & Realisasi & $\begin{array}{c}\text { Persentase } \\
\text { (\%) }\end{array}$ \\
\hline $\mathbf{1}$ & Jan-17 & 46.200 & 36.505 & $79 \%$ \\
\hline $\mathbf{2}$ & Feb-17 & 46.200 & 29.278 & $63 \%$ \\
\hline $\mathbf{3}$ & Mar-17 & 46.200 & 47.500 & $103 \%$ \\
\hline $\mathbf{4}$ & Apr-17 & 46.200 & 26.875 & $58 \%$ \\
\hline $\mathbf{5}$ & Mei-17 & 46.200 & 33.661 & $73 \%$ \\
\hline $\mathbf{6}$ & Jun-17 & 46.200 & 9.933 & $22 \%$ \\
\hline $\mathbf{7}$ & Jul-17 & 46.200 & 21.045 & $46 \%$ \\
\hline $\mathbf{8}$ & Agust-17 & 46.200 & 37.747 & $82 \%$ \\
\hline $\mathbf{9}$ & Sep-17 & 46.200 & 26.243 & $57 \%$ \\
\hline $\mathbf{1 0}$ & Okt-17 & 46.200 & 33.776 & $73 \%$ \\
\hline $\mathbf{1 1}$ & Nop-17 & 46.200 & 33.350 & $72 \%$ \\
\hline $\mathbf{1 2}$ & Des-17 & 46.200 & 34.037 & $74 \%$ \\
\hline $\mathbf{1 3}$ & Jan-18 & 46.200 & 31.363 & $68 \%$ \\
\hline $\mathbf{1 4}$ & Feb-18 & 46.200 & 34.856 & $75 \%$ \\
\hline \multicolumn{7}{c}{ Rata-Rata } & $\mathbf{3 1 . 1 5 5}$ & $\mathbf{6 7 \%}$ \\
\hline
\end{tabular}

Sumber: Data produksi CV. Budi Jaya Abadi ; 2018

Berdasarkan tabel 1 dapat diketahui bahwa perusahaan dihadapkan dengan permasalahan dalam pencapaian target produksi. Hal ini terlihat dari jumlah produksi yang dihasilkan selama 12 bulan terakhir dengan ratarata produksi sebanyak 31.155 potong per bulan atau hanya sebesar $67 \%$, sedangkan perusahaan telah menetapkan target produksi celana setiap bulan nya adalah sebanyak 46.200 potong. Dengan demikian dapat dikatakan bahwa produktivitas masih belum optimal, bukan hanya tidak dapat mencapai target produksi tetapi juga terjadi fluktuasi selama 12 bulan tersebut dengan penurunan yang cukup signifikan yaitu pada bulan Juni 2017 yang hanya memproduksi sebanyak 9.933 potong atau sebesar $22 \%$. Selain faktor diatas terdapat pula faktor yang sangat dominan yang menyebabkan tidak tercapainya target produksi yaitu loyalitas karyawan, hal ini diperkuat dengan kondisi lapangan yang menggambarkan bahwa kurangnya kesadaran dari karyawan terhadap tanggung jawab atas pekerjaan yang seharusnya mereka kerjakan.

Berdasarkan data karyawan, dapat dilihat bahwa karyawan masuk ke perusahaan pada Bulan Juli 2017 dari 25 karyawan diatas, 52\% karyawan bertahan diperusahaan hanya sekitar 1 minggu - 1 bulan, 20\% karyawan bertahan diperusahaan hanya sekitar 2 bulan, 4\% karyawan bertahan diperusahaan hanya sekitar 3 bulan, $12 \%$ karyawan bertahann diperusahaan hanya sekitar 4 bulan, karyawan bertahann diperusahaan hanya sekitar 5 bulan. Banyak faktor yang mempengaruhi produktivitas kerja karyawan salah satunya adalah loyalitas karyawan. Penelitian ini tentang Pengaruh Loyalitas Karyawan Terhadap Produktivitas Kerja Pada Cv. Budi Jaya Abadi Garut.

\section{KAJIAN PUSTAKA}

Kesetiaan atau komitmen organisasi telah menjadi salah satu topik paling menarik diteliti sejak 1960-an. Banyak penelitian telah dilakukan pada kesetiaan dan dampaknya tentang produktivitas karyawan[6].

Karyawan yang loyal yang puas dengan pekerjaannya menunjukkan kesetiaan mereka kepada organisasi dengan bekerja keras dan berkomitmen untuk memberikan layanan dengan tingkat kualitas tinggi kepada pelanggan[7].

Loyalitas memiliki bentuk aktif dan pasif [8]. Dalam menanggapi masalah kerja, karyawan dapat tetap diam tanpa menyadari perlunya respons lain (loyalitas tidak sadar), sengaja tetap diam untuk melihat apa yang akan terjadi (loyalitas pasif), atau secara aktif mempertahankan organisasi dengan memberikan alternatif dan tindakan positif pada masalah tersebut. (Loyalitas reformis)[9]. 
Produktivitas secara umum didefinisikan sebagai hubungan antara fisik atau nyata yang dapat berupa barang-barang atau jasa. Produktivitas merupakan ukuran efisiensi dari produktif yang didapat dari membandingkan antara hasil keluaran dan masukan[10].

\section{METODE PENELITIAN}

Metode yang digunakan dalam penelitian ini adalah metode deskriptif verifikatif. Metode deskriptif merupakan cara mendeskripsikan atau menggambarkan data yang telah terkumpul sebagaimana adanya tanpa bermaksud membuat kesimpulan yang berlaku untuk umum atau generalisasi. Sedangkan metode verifikatif merupakan penelitian yang dilakukan terhadap populasi atau sampel tertentu dengan tujuan untuk menguji hipotesis yang telah ditetapkan.

Adapun yang menjadi variabel dalam penelitian ini adalah sebagai berikut: Variabel Independen (Variabel Bebas) adalah Loyalitas Karyawan (X). Variabel Dependen (Variabel Terikat) adalah Produktivitas Kerja (Y). Populasi dalam penelitian ini adalah karyawan CV. Budi Jaya Abadi Garut khususnya Departemen Jahit sebanyak 324 karyawan.

Pengambilan sampel dalam penelitian ini dengan teknik probability sampling yaitu proportionate stratified random sampling dengan menggunakan rumus slovin. Besarnya sampel dalam penelitian ini ditentukan dengan rumus Slovin adalah sebanyak 76 karyawan.

\section{HASIL DAN PEMBAHASAN}

Analisis regresi sederhana digunakan untuk mengetahui pengaruh informasi akuntansi diferensial terhadap pengambilan keputusan manajemen.

Tabel 2 Koefisien Regresi

\section{Coefficients}

\begin{tabular}{|l|r|r|r|r|r|}
\hline & \multicolumn{1}{|c|}{$\begin{array}{c}\text { Unstandardized } \\
\text { Coefficients }\end{array}$} & $\begin{array}{c}\text { Standardiz } \\
\text { ed } \\
\text { Coefficien } \\
\text { ts }\end{array}$ & & \\
\cline { 2 - 4 } Model & B & \multicolumn{1}{c|}{$\begin{array}{c}\text { Std. } \\
\text { Error }\end{array}$} & Beta & T & Sig. \\
\hline $1 \quad$ (Constant) & 32.359 & 4.634 & & 6.983 & .000 \\
\multicolumn{1}{|c|}{$\begin{array}{l}\text { Produktivitas } \\
\text { Kerja }\end{array}$} & .364 & .130 & .309 & 2.796 & .007 \\
\hline
\end{tabular}

a. Dependent Variable: Loyalitas

Karyawan
Dengan persamaan regresi linier sederhana sebagai berikut:

$$
\mathrm{Y}=32,359+0,364 \mathrm{X}
$$

Data diolah secara statistik disebut signifikan secara statistik untuk keperluan analisis dan pengujian hipotesis dengan menggunakan alat bantu program software IBM SPSS 20.

Koefisien determinasi adalah seberapa besar kemampuan semua variabel bebas dalam menjelaskan varians dari variabel terikatnya.. Pengukuran besarnya persentase kebenaran dari uji regresi dapat dilihat melalui nilai koefisien determinasi multiple $\mathrm{R}^{\wedge} 2$.

Tabel 3 Koefisien Determinasi Model Summary

\begin{tabular}{|r|r|r|r|r|}
\hline Model & \multicolumn{1}{|c|}{$\mathrm{R}$} & $\mathrm{R}$ Square & \multicolumn{1}{c|}{$\begin{array}{c}\text { Sdjusted R } \\
\text { Square }\end{array}$} & $\begin{array}{l}\text { Std. Error of } \\
\text { the Estimate }\end{array}$ \\
\hline 1 & $.209^{\mathrm{a}}$ & .496 & .083 & 2.513 \\
\hline
\end{tabular}

a. Predictors: (Constant), Produktivitas Kerja Dengan perhitungan dan penjelasan sebagai berikut :

$\mathrm{Kd}=\llbracket \mathrm{r} \rrbracket \wedge 2 \times 100 \%=0,496 \times 100 \%=49,6 \%$

Dalam penelitian ini ditetapkan hipotesis melalui pengujian secara individual (parsial) rancangan pengujian hipotesis penelitian ini.

Tabel 4 Uji Hipotesis (Uji T)

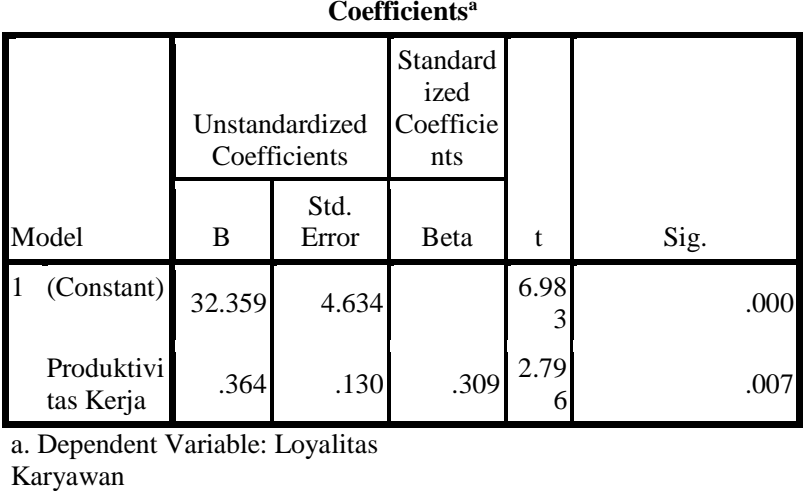

Berdasarkan tabel 4, diperoleh nilai thitung untuk Loyalitas Karyawan sebesar 2.796 dengan nilai Sig. 0,007 . Untuk mengetahui hasil pengujian hipotesisnya maka nilai thitung tersebut dapat dibandingkan dengan nilai ttabel $(0,05 ; 76-2-1)$ sebesar 1,67 . Sesuai dengan kaidah keputusan nilai t hitung $>\mathrm{t}$ tabel atau $2.796>$ 1,67 artinya H0 ditolak, maka secara signifikan Loyalitas Karyawan berpengaruh terhadap Produktivitas Kerja pada CV. Budi Jaya Abadi Garut. 
Tabel 5 Rekapitulasi Tanggapan Responden Mengenai Variabel Loyalitas Karyawan

\begin{tabular}{clcc}
\hline No. & \multicolumn{1}{c}{ Dimensi } & Rata-rata & Keterangan \\
\hline $\mathbf{1}$ & Ketaatan & 275 & Baik \\
\hline $\mathbf{2}$ & Pengabdian & 272 & Cukup Baik \\
\hline $\mathbf{3}$ & $\begin{array}{l}\text { Tanggung } \\
\text { Jawab }\end{array}$ & 277 & Baik \\
\hline & & \\
\hline & Rata-rata & $\mathbf{2 7 4}$ & Cukup Baik
\end{tabular}

Berdasarkan tabel 5 diatas, dapat dilihat bahwa secara keseluruhan tanggapan respoden mengenai loyalitas karyawan CV. Budi Jaya Abadi Garut cukup baik. Hal ini menunjukkan bahwa kesetiaan karyawan terhadap perusahaan sudah cukup baik

Tabel 6 Rekapitulasi Tanggapan Responden Mengenai Variabel Produktivitas Karyawan

\begin{tabular}{clcc}
\hline No. & Dimensi & $\begin{array}{c}\text { Rata- } \\
\text { rata }\end{array}$ & Keterangan \\
\hline $\mathbf{1}$ & Efektivitas & 258 & Cukup Baik \\
\hline $\mathbf{2}$ & Efisiensi & 276 & Baik \\
\hline $\begin{array}{c}\text { Rata- } \\
\text { rata }\end{array}$ & & $\mathbf{2 6 7}$ & Cukup Baik \\
\hline
\end{tabular}

Berdasarkan tabel 6 diatas, dapat dilihat bahwa secara keseluruhan tanggapan responden mengenai variabel produktivitas kerja dengan rata-ratasebesar 267 termasuk dalam kategori cukup baik

\section{KESIMPULAN DAN SARAN}

Loyalitas Karyawan yang meliputi Ketaatan, Pengabdian, dan Tanggungjawab secara keseluruhan Loyalitas Karyawan pada CV. Budi Jaya Abadi Garut berdasarkan hasil tanggapan responden yang cukup baik. Produktivitas Kerja yang meliputi Efektivitas dan Efisiensi secara keseluruhan Produktivitas Kerja pada CV. Budi Jaya Abadi Garut berdasarkan hasil tanggapan responden yang cukup baik.

Berdasarkan hasil pengujian hipotesis dengan Uji$\mathrm{T}$ diperoleh nilai thitung untuk variabel Loyalitas Karyawan sebesar 2.796 dengan nilai ttabel sebesar 1,67 maka $2.796>1,67$, sesuai dengan hipotesis bahwa thitung > ttabel maka $\mathrm{H} 0$ ditolak yang artinya Terdapat Pengaruh Loyalitas Karyawan terhadap Produktivitas Kerja pada CV. Budi Jaya Abadi Garut.

\section{REFERENSI}

[1] N. A. Hamdani, T. Susanto, and G. Abdul Fatah Maulani, "Framework of Architectural Marketing Capabilities in Regional Development Bank," Int. J. Eng. Technol., vol. 7, no. 3.25, pp. 166-169, 2018.

[2] A. Supriyatna, E. Yulianto, N. A. Hamdani, and G. A. F. Maulani, "Budaya Perusahaan: Penerapan Good Corporare Governance Serta
Implikasinya Terhadap,” Bus. Innov. Entrep. J., vol. 1, no. 1, pp. 11-20, 2019.

[3] G. Colovic, "The Garment Industry Problems," J. Text. Sci. Eng., vol. 04, no. 05, p. 100168 , 2014.

[4] M. C. Horne, R., de Andrade, "Gambaran beragam untuk sektor garmen Indonesia," 2017.

[5] G. Chrysler-Fox, Pharny and Roodt, "Changing Domains in Human Capital Measurement," $J$. Hum. Resour. Manag., vol. 12, no. 1, pp. 1-12, 2014.

[6] M. Ibrahim and S. Al Falasi, "Employee loyalty and engagement in uae public sector," Empl. Relations, vol. 36, no. 5, pp. 562-582, 2014.

[7] R. W. Y. Yee, A. C. L. Yeung, and T. C. Edwin Cheng, "An empirical study of employee loyalty, service quality and firm performance in the service industry," Int. J. Prod. Econ., vol. 124, no. 1, pp. 109-120, 2010.

[8] K. Matzler and B. Renzl, "Total Quality Management \& Business The Relationship between Interpersonal Trust , Employee Satisfaction, and Employee Loyalty The Relationship between Interpersonal Trust, Employee Satisfaction, and Employee Loyalty," Total Qual. Manag., vol. 17, no. 10, pp. 1261-1271, 2006.

[9] B. P. Niehoff, M. R. Truitt, R. H. Moorman, R. B. Daugherty, G. Blakely, and J. Fuller, "The Influence of Empowerment and Job Enrichment on Employee Loyalty in a Downsizing Environment," Gr. Organ. Manag., vol. 26, no. 1, pp. 93-113, 2001.

[10] K. Bourletidis, "The Strategic Management of Market Information to SMEs during Economic Crisis," Procedia - Soc. Behav. Sci., vol. 73, pp. 598-606, 2013. 